\title{
14
}

\section{The prehistory of Rapa Island}

\author{
Atholl Anderson \\ Department of Archaeology and Natural History, Research School of Pacific and Asian Studies, The Australian \\ National University, Canberra, Australia, atholl.anderson@anu.edu.au \\ Douglas J. Kennett \\ Department of Anthropology, The Pennsylvania State University \\ Eric Conte \\ Université du Polynésie Française
}

\section{Introduction}

Rapa is a small, high and substantially isolated volcanic island lying in East Polynesia at the temperate edge of the subtropical South Pacific. Discovered by Europeans in 1791, Rapa has been the subject of lengthy ethnological and anthropological fieldwork but relatively little archaeology and that directed almost entirely at the hilltop fortifications that dominate the landscape. Our fieldwork, during six weeks in the winter of 2002, has produced sufficient variety and abundance of material from archaeological sites (Appendix D) and palaeoenvironmental research to enable the sketching of a first prehistory of Rapa.

Before turning to that, it is worth noting that we saw no evidence during fieldwork or subsequent analyses of the proposed connection to Easter Island that infused 19th century speculation about Rapan archaeology and drove the only substantial investigations that had occurred previously on Rapa, by the Norwegian Archaeological Expedition (Chapter 1). To the contrary, there is no historical support for the name 'Rapa-iti' as a derived companion to 'Rapanui' with colonisation implications; the Rapan language is part of the same southeastern group that includes Mangarevan and Rapanuian, but it is not closer to the latter (Chapter 2); none of the classic Easter Island architectural forms were reproduced on Rapa, nor did Rapa obtain the chicken, sweet potato or most of the other cultivable plants that existed on Easter Island. It is possible that migrants from Rapa reached other islands, including New Zealand, as has been conjectured in relation to the forts, but the evidence is slight, because fortification occurred widely in Polynesia, and New Zealand's typical ditch-and-bank constructions are very different from the stone-faced terraces of Rapa.

This is not to assert that there was no prehistoric movement to or from Rapa. The Rapan traditions suggest some additional arrivals after initial colonisation, and the evident familiarity 
of Rapans with iron at first European contact also implies external contact (Chapter 2), but evidence of connections is otherwise scarce. Archaeologically, there is no obsidian, which might have come from Pitcairn Island or Easter Island, and no pearl shell, which could have been brought from the more tropical Austral, Society, Tuamotu or Gambier islands. While further research might show evidence indicative of more regular contact, our working hypothesis has been that the development of archaeological features on Rapa through the pre-European era reflects events and contingencies of colonisation followed by adaptation and innovation that occurred very largely in isolation.

Our project focused on questions about the chronology of human colonisation, the nature of settlement and subsistence, landscape change and the rise of fortifications.

\section{Chronology of colonisation}

The chronology of colonisation was investigated through sedimentary coring and archaeological research. The palynological record (Chapter 10) indicates that coastal swamp forests expanded on the island after about $500 \mathrm{BC}$ in response to changing sedimentary conditions following a mid-Holocene high-stand in sea level. After about AD 1000, there was rapid sediment accumulation in the embayments around Rapa, and at Tukou in Ha'urei Harbour. At Tukou, sedimentation was associated with a decline in swamp forest, a rise in Pandanus and an onset of high concentration in charcoal particles. Radiocarbon ages for the onset of microcharcoal concentrations in the Tukou cores vary from 130 BC to about AD 1200 and are consistently older than the earliest age determinations for human colonisation evident in the archaeological record, although all radiocarbon ages for peaks in microcharcoal concentration occur within the span of archaeological chronology (after AD 1000). This is typical of many charcoal profiles in Pacific swamps and it is thought to represent infrequent natural fires followed by the substantially increased rates of cultural ignition. Radiocarbon ages on charcoal for the beginnings of plant cultivation, as represented by the onset of pollen deposition from taro (Colocasia esculenta), generally overlap the beginning of the archaeological chronology. However, the strongest age estimate, from Core 2 at Tukou, is about AD 1020, more than 200 years older than the earliest archaeological determination for the island. This is possibly due to the mixing of sediment by early agricultural activities in these wetland contexts (Chapter 10).

The initial phase of human colonisation is represented archaeologically by a set of dates from Tangarutu rockshelter (chapters 3 and 11), which is by far the largest and most habitable of the rockshelters on Rapa. All the relevant dates are from basal cultural deposits underlain by clean carbonate sand that goes down to the basalt boulders and in situ floor of the rockshelter (Chapter 3). The earliest date came from a small test probe below the base of a modern sand mining pit in the middle of the rockshelter floor. The sand was too loose to allow an excavation and even the core sample was difficult to obtain. The date is from the ANU radiocarbon dating laboratory, and as with many later results from that laboratory, it has very large standard errors, extending in this case from AD 600 to 1400. In our Bayesian analysis, this anomalously early date is constrained to AD 1000-1400 based on the other early dates for the island, with peak probability between $A D 1000$ and 1400. It is, at least, consistent with the earliest precise AMS ${ }^{14} \mathrm{C}$ date (UCIAMS-14769) of AD 1100 to 1200 on comparable deposits. The phase boundary for initial colonisation has been modelled as about AD 800 to 1300, with peak probability between $\mathrm{AD} 1100$ and 1200. The phase boundary ends between AD 1300 and 1600 with peaks between $\mathrm{AD} 1400$ and 1500. The fairly wide age distributions for these phase boundaries, compared with later phases, is related to the smaller number of dates used to define the colonisation phase (Chapter 11). 
On these two data sets, the age of onset of human colonisation still remains less precise than was expected. The archaeological data suggest reasonably clearly that the 12th century was the most probable period of human arrival (Chapter 11). The data from sedimentary cores are more problematic, with some evidence indicative of cultural influence in the 11th century and even considerably earlier than that, although the data are few. There are, however, plausible reasons for thinking that the record of microcharcoal concentration in the samples from sedimentary cores includes non-cultural evidence. Some radiocarbon dating samples that had the appearance of charcoal could actually have been, or included, wood tissue blackened in the reducing environment of swamp water, and some microcharcoal concentrations might represent natural firing. As the dates referring to taro pollen were on charcoal samples, the same uncertainty exists (Chapter 10). The span of colonisation could probably be specified more precisely and narrowed further through more radiocarbon dating, but our chronological hypothesis at present is that there was no human colonisation of Rapa before the 12th century AD. Colonisation at that time is consistent with initial human dispersal throughout central East Polynesia (Wilmshurst et al. 2011) and shows that even quite remote islands were reached in this phase.

\section{Coastal settlement and subsistence}

Our radiocarbon chronology shows that settlement, measured by occupation of rockshelters, expanded in coastal areas of Rapa between AD 1400 and 1600. Most of the Tangarutu occupational sequence dates to this interval. The second and third largest rockshelter complexes on Rapa, at Akatanui and Angairao, were used first in this period, as were the small Taga rockshelters on the mid-slope of Ha'urei Harbour (Chapter 11). It is very probable that there were settlements on open ground, for example in the coastal flats at the head of the harbour and in most large bays, in the period AD 1400-1600. Earth ovens and terraces around the shores of Ha'urei Harbour, sectioned by road cutting and erosion, or investigated by coring or spade pits, produced radiocarbon dates extending back to about AD 1200. As the terraces are about the size suitable for a domestic unit, often around $8 \mathrm{~m}$ by $12 \mathrm{~m}$, and sometimes have remains of ovens or graves, they probably supported individual households. However, neither postholes in section, nor cultural deposits across the floors were found in our preliminary investigations of the Ha'urei sites. In addition, exploratory coring of sand dunes and other sedimentary features in the outer bays did not pick up any evidence of buried occupational levels (Chapter 3).

Judging by excavations in rockshelters (and in hilltop forts, below), subsistence from the beginning of settlement on Rapa was reliant on fishing, foraging and the cultivation of taro.

\section{Coastal fowling, fishing and shellfishing}

The list of animal resources available on Rapa was short. Pacific rat bone occurred throughout archaeological deposits, but no dog, pig or chicken bone was found in any context that was plausibly pre-European. No seal bone was recorded and the only reptile remains were from marine turtle. Of 118 birds, identified to 15 species, $90 \%$ were seabirds. About half of all bones were from the Kermadec petrel, and that species plus the little shearwater, red-tailed tropic bird, grey noddy, brown noddy, white-bellied storm petrel and white tern, which were also represented in the archaeological material, are still breeding on Rapa. Among landbirds, remains of a Gallirallus indicate that Rapa, like most Pacific islands, once had more species of rail. Bones of a large Ducula pigeon species and of a Cyanoramphus parakeet indicate other extinct taxa (Chapter 6).

Fishing was clearly of primary importance in Rapan subsistence, and fishing patterns were rather unusual. At Tangarutu, the oldest level shows a dominance of Scaridae, which gave way 
to a dominance by Chaetodontidae and Muraenidae in the middle level, and Muraenidae, plus Scaridae and Serranidae, in the upper level. Muraenidae and Congridae eels are generally very scarce archaeologically in Pacific Island archaeological assemblages, and the high incidence of Chaetodontidae also represents the first positive identification of this family in a Pacific assemblage. Labridae, Serranidae, Muraenidae and Congridae are the other main families represented (Chapter 7). The inter-site differences probably reflect variation between leeward and windward inshore ecologies, but intra-site temporal changes are more difficult to interpret. The rocky coasts of Rapa may have supported comparatively large and accessible populations of marine eels, and large freshwater eels (Anguillidae) are common in streams and taro ponds. The latter were avoided, as they are today, but marine eels are represented in the Rapan middens to an extent matched only on Easter Island. As Rapa and Easter Island have similar inshore ecologies and also are both isolated, the catch in each case may have been shaped by resolutely inshore fishing of taxa in which the major species were those locally common (Chapter 7).

The abundance of Pomacentridae and Chaetodontidae needs to be seen in the context of a generally small size of fish in all families represented in the Rapan assemblages. In the lowest level at Tangarutu there are some remains of larger fish, but as most are small, fish size in the Rapan sites is probably not an effect of over-exploitation. Sampling effects caused by our very small excavations, or social division of catches, cannot be ruled out, but the small fish size occurred both at Tangarutu and Akatanui, and in every other assemblage (Chapter 7; Butler, Appendix C). We suspect that fishing technology was the main factor involved. It is apparent from the absence of trolling lures, of large hooks or points from large composite hooks, and of remains from large benthic or pelagic taxa that open-sea and deep-sea fishing was not common, perhaps because of the danger of being lost in such an isolated location. In turn, this possibly resulted from the absence of a sailing technology capable of bringing canoes back to the island in varied wind conditions. The very small size of most of the Rapan hooks found archaeologically, and known ethnographically, suggests that small fish were being targeted in this method, and it is probable that fine-meshed nets and traps were also employed routinely. Relatively cool ocean temperatures might also have produced smaller mature sizes of fish in families that exhibited larger mean sizes in tropical waters (Chapter 7).

The shellfishing data from Tangarutu show evidence of a transition from hard-shore towards soft-shore collecting within the context of a dominance of algal grazing taxa (Chapter 8). The urchin Diadema setosum, in particular, is a prominent algal grazer. As algal-grazing fish such as scarids, pomacentrids and chaetodontids dominate the Tangarutu assemblage, the fish, urchin and shell data from Tangarutu imply, together, that Anarua Bay supported extensive hard substrates on which grew micro-algal turf. Oscillations in frequencies of different algalgrazing molluscs, urchins and fish taxa in the catch data suggest complementary changes among vertebrate and invertebrate algal feeders. Thus, sporadic high levels of Diadema occurrence probably resulted from fishing pressure on competing algal-grazing fish; strong initial pressure on Scaridae might have promoted the relative abundance of other algal-grazing taxa and later the pressure on those could have promoted a return to greater numbers of scarids, for which the small candlenut hooks were developed late in the sequence (Chapter 9). Overall, variations in catches within the marine exploitation data suggest a rise in the employment of angling relative to nets and traps, and movement of shellfishing into the soft-shore bayheads, within a pattern of resource use that was changing continually according to complex inter-relationships between algal-grazing taxa (Chapter 9). 
Plant foods and fibres

Just as Rapa lacked all of the domestic animals of Remote Oceania, so it lacked key crops, notably coconut, breadfruit, yam and sweet potato, as well as most, if not all, bananas. Pandanus (Pandanus tectorius and probably other species) produced edible fruits. Pith of the tree fern (Cyathea medullaris) may have been consumed, as it is today, and pith from Marattia spp. and Angiopteris spp. was also potentially available, but these and the rhizomes of ground ferns such as Histiopteris incisa, Dryopteris sp. and Dicranopteris linearis were rudimentary starch sources at best. Species introduced prehistorically that had food value, as well as other properties of fibre or fruits in some cases were: candlenut (Aleurites moluccana), bottle gourd (Lagenaria siceraria), taro (Colocasia esculenta) and tii (Cordyline cf. fruticosa). At least two timber trees, the miro (Thespesia populnea) and hau or hibiscus (Talipariti tiliaceum syn. Hibiscus tiliaceus), were probably introduced, and also the coral wood (Erythrina variegata), which produced ornamental flowers - along with hibiscus flowers, an essential component of social life in Polynesia. Archaeological charcoals show that tii and hau had been used as firewood in the lowest level at Tangarutu, and candlenuts occurred throughout the sequence and in other rockshelter deposits, being notably abundant at Akatanui (Chapter 4). The existence of these introduced materials in the earliest recorded archaeological levels implies that initial colonisation had occurred earlier still, but perhaps not much earlier.

In the upper level at Tangarutu, lenses of leafy remains produced fragments of plaited Pandanus and Freycinetia (Pandanaceae) baskets or mats. There were also fragments of bottlegourd rind, dated earliest to about AD 1600, and many Pandanus keys. Knotted cordage made from Broussonetia papyrifera (paper mulberry), braided cordage worked from the roots of Freycinetia spp. (kiekie vine) and twisted cordage from Hibiscus also occurred in this level (Chapter 5).

\section{Agriculture}

Pollen profiles show that the natural wetlands on Rapa were being used for taro production early and extensively. They seem to have been used continuously throughout Rapan prehistory (starting sometime between AD 1100 and 1200), along with constructed pondfields on higher ground. Remnant pondfield systems can be seen in each of the major bays and the main harbour, and overall they occupy an area (about 84 ha) some 20 times greater than the extent of the modern pondfields (Chapter 13). A general absence of observable charcoal in the pondfield structures and insufficient time or resources to embark on a systematic subsurface investigation prevented our obtaining any information about the development and use of these systems through the prehistoric era. Their distribution through all available bays and the plausible linkage of each system to nearby hilltop forts, or to apparent remnant hamlets at lower levels, suggest that at one stage, if only in late prehistory, they were all in use at once. On that assumption, and given an $80 \%$ dietary contribution of taro from pondfield systems, including $20 \%$ diverted away from direct consumption (waste, trade, tribute, etc), an island population of around 2000 people could have been sustained (Chapter 13). Lower estimates of the dietary contribution of taro would produce larger population sizes, and some historical data suggest, though very imprecisely, that there might have been around 3000 people living on Rapa before the impact of European disease (Chapter 2).

\section{Chronology, characteristics and purpose of forts}

No aspect of the landscape or history has been so widely the subject of commentary as the forts (pare) that stand out dramatically along the Rapan skyline. They beg the question of 
what circumstances drove such an investment in fortification and our research has attempted to answer that by investigating the chronology of construction and material evidence of the purposes served by these structures.

\section{Chronology of construction}

Thirty AMS radiocarbon dates, analysed by Bayesian methods, help to put fort construction into a general sequence. As most of the construction occurred after about AD 1700, when the radiocarbon calibration curve has strong fluctuations that obscure precise determination of age, we used the evidence from mission records that fortified villages were abandoned by AD 1825 to constrain the probability distributions (Chapter 11). Radiocarbon dating places initial fortification at Noogorupe and Ruatara between AD 1300 and 1400, approximately 200 years after initial island settlement. There may have been historical connections between the occupants of Tangarutu rockshelter in Anarua Bay, seemingly a colonisation settlement, and those who used the ridgeline above the bay and built the Noogorupe fort, which overlooks Anarua and Ha'urei Harbour. Similarly, the contemporary establishment of Ruatara possibly resulted from fissioning of the founding community at Anarua.

Settlement continued at Ruatara up to about AD 1800, and also at Noogorupe, with a possible hiatus between AD 1400 and 1650. Morongo Uta appears to have been established between $A D 1500$ and 1600 and it continued until about AD 1800. Most other forts were constructed or occupied between AD 1700 and 1830, with a general increase in construction after $\mathrm{AD} 1750$. Seven forts date to the early 1700 s and at least 10 forts to the late 1700 s. Smaller forts also date to the late 1700s - e.g. Tauo, Ngapiri, Pukutai and Pukumia (chapters 11 and 12). Investigations at Potaketake suggest that dyke-stone masonry developed after AD 1750 and most sites with dyke-stone masonry have components that date after this time. Ororangi appears to be the only site dating to between $\mathrm{AD} 1750$ and 1830 where masonry architecture was not used (Chapter 12).

\section{Characteristics of forts}

Archaeological survey and small-scale excavation occurred at 10 large and four small forts (Chapter 12). All of the larger forts are strategically positioned on the highest points along the main ridge surrounding Ha'urei Bay. The sites range in size between $3040 \mathrm{~m}^{2}$ (Noogorupe) and $25,237 \mathrm{~m}^{2}$ (Tapitanga). At the core of each fort is a central tower carved from a high point in the weathered basalt ridge and surrounded by one to two large terraces. Terraces extend out from those site cores along ridges or down the slopes at the head of surrounding valleys. The smaller forts are often found in close proximity to the larger forts and they are considered to be satellite communities or temporary refugia. Two of the four smaller forts have central towers.

The number of terraces per fort varies considerably and is not clearly related to site size. Potaketake was $5744 \mathrm{~m}^{2}$ and has ca. 30 terraces. Tapitanga has a similar number of terraces (ca. 42) dispersed over a much larger area $\left(25,237 \mathrm{~m}^{2}\right)$. There is a tendency for terraces along flat ridgelines to be rectilinear in shape and for those on steeper terrain to be $\mathrm{d}$-shaped. Natural slabs of dyke stone were used widely in masonry and facing. The most extensive natural dykestone deposits are in the vicinity of Noogorupe and there is some evidence that these deposits were quarried. Towers were commonly covered with dyke-stone masonry facades and rectilinear terraces formed by cut-and-fill were usually reinforced with dyke stone laid in parallel series as masonry walls. None of the walls reach above the level of the terrace and they were not constructed to be weight-bearing. Tapitanga and Ororangi stand out as exhibiting very little evidence of dyke-stone masonry (Chapter 12). 
Structures made from perishable materials, most probably houses or huts, were constructed on these platforms, their positions indicated by remains of hearths. Around them are scatters of midden comprising charcoal, bone and burnt or flaked stone. The midden is mostly of fish bone, and among it, Scaridae is dominant (Chapter 12; Butler, Appendix C), as at Tevaitau, Orotangi, Ruatara and Tapitanga. Additional taxa are also similar to those found in the coastal sites: Pomacentridae, Labridae, Muraenidae etc. Rat bones (Rattus sp.) were also recovered.

The inhabitants of these hilltop settlements were probably also reliant on the wet taro agriculture of lowland pondfields, and the limited distribution of agricultural land may be one reason why settlements moved increasingly to ridgelines and hilltops. These localities were also suitable for storage and protection of harvested crops, probably in the large and small pits that are evident at most of the forts (Chapter 12).

\section{The purpose of forts}

Several hypotheses have been advanced to account for the construction of forts on Rapa. Through the telescopes of Vancouver and his officers in 1791 (Lamb 1984) they appeared as fortified habitations with people clustered in them, but in the 19th century, when the structures were manifestly uninhabited, the view prevailed that they were simply fortresses or redoubts used as places of refuge and defence during times of war. In the early 20th century, Peter Buck (1954), with New Zealand experience in mind, thought them rather like Maori pa, which were often inhabited, though not necessarily continuously. The Norwegian archaeological investigations (Heyerdahl and Ferdon 1965), especially the huge effort of exposure and excavation on Morongo Uta, concluded that they were, indeed, fortified villages (Chapter 1).

More recently, however, Jerome Walczak (2003) has argued that the structures served primarily ritual functions. Given that East Polynesian hierarchies had a powerful ritual dimension that served to legitimise established social and political order, it can hardly be doubted that pare were localities of ritual function. The same, of course, would have been true of settlements around the coast. If the argument is made in archaeological terms, then slight evidence of ritual activity in the pare, such as the small alcoves with upright stones set into walls at Morongo Uta, needs to set against substantial evidence of fortification, habitation platforms, ovens and middens. Our research at multiple locations is consistent with the hypothesis that these sites were, substantially, defended residential complexes.

We argue that as political and social hierarchy is embedded in East Polynesian culture, it was certainly carried to Rapa. It first becomes apparent archaeologically with the establishment of the Noogorupe and Ruatara fortifications between AD 1300 and 1400, the new need for defensive architecture implying the beginning of stronger status rivalry between competing polities than existed at the time of initial colonisation or developed soon afterward. If it is accepted, as ethnographic data suggest, that the flat-topped towers at the centres of large forts were places of chiefly habitation, then 10 competing chiefly polities existed on Rapa by the 18th century. Pare at that time tended to have more defensive features (e.g. Morongo Uta, Potaketake, Kapitanga), some of which cut through existing architecture, suggesting improvements to defensive structure. The higher elevation refugia sites (Ngapiri and Pukumia) also suggest increased warfare late in the Rapan sequence. The overall trend in fort construction, from two in the 14 th century, gradual increases into the 17 th century and an accelerated burst through the 18 th century, suggests that conflict and the threat of war increased through the sequence. The most likely reasons for this increase were either direct population growth or indirect population pressure on resources, such as agricultural land. 


\section{The subtropical depriment}

Rapa is one of a series of Polynesian islands that lie in the subtropical zone below the Tropic of Capricorn. Others are: the Norfolk Islands, the Kermadec Islands, Raivavae, the Pitcairn Group (including Pitcairn, Henderson, Oeno and Ducie) and Easter Island. Leaving aside Raivavae, which has an extensive encircling lagoon, and the two small atolls (Oeno and Ducie), the subtropical islands are distinguished by their virtual absence of coral lagoons. ${ }^{1}$ The loss of diversity and biomass in marine resources that this represents is a significant deficit for long-term settlement relative to tropical Polynesia. In addition, the absence for climatic reasons of some tropical Polynesian native food plants and the difficulty or impossibility of growing coconut or breadfruit reduced the value of the terrestrial resource array. Equally, the low number of breeding sea birds (and the virtual absence of seals) was a significant deficit relative to temperate South Polynesia (Anderson 1996). In other words, the subtropical islands lay unfavourably between the lagoonal and agricultural landscapes to the north and the resource landscapes to the south rich in marine birds and mammals (Anderson 2001, 2002). They suffered from what can be called 'the subtropical depriment', i.e. the depression in resource opportunity for human settlement that resulted from subtropical geography and climate.

It was further exacerbated by the fact that most subtropical islands were small (Pitcairn $5 \mathrm{~km}^{2}$, Norfolk, Raoul, Rapa, Henderson 29-38 $\mathrm{km}^{2}$ ), lacking bays or harbours, and notably remote. Pitcairn is $524 \mathrm{~km}$ from Mangareva, Rapa $537 \mathrm{~km}$ from Raivavae, Norfolk $733 \mathrm{~km}$ and Raoul 980 km respectively from New Zealand, and Easter Island $1915 \mathrm{~km}$ from Henderson Island. Only the relatively large Easter Island $\left(164 \mathrm{~km}^{2}\right)$ and Rapa, by the advantage of its large harbour and associated coral reefs in creating a lagoonal surrogate, were inhabited continuously into the European era. Small size meant that population growth soon reached territorial and resource limitations. Remoteness reduced both the range of resources that arrived during colonisation and those that could be readily obtained later. There is no evidence that food crops reached either Norfolk or the Kermadecs in the prehistoric era (although banana was growing on the former by 1788), and they were relatively limited on the other subtropical islands: Rapa had taro, ti, gourd and candlenut, possibly banana; Henderson had coconut, ti, swamp taro and candlenut. Easter Island had sweet potato, taro, yam, banana and sugarcane, a range sufficiently large to suggest that initial colonisation might have involved a number of canoes or some twoway voyaging. Other than the almost ubiquitous Polynesian rat (Rattus exulans), the dispersal of animals was slight: possible dog on Norfolk and Easter Island, dog on Raoul, chicken on Easter and pig on Henderson (Anderson 1981; Weisler 1996; Anderson and White 2001; Mieth and Bork 2004).

Overall, then, the subtropical islands were prone to occupational stress caused by a variety of factors and it is difficult to say that the histories of settlement were influenced more by one factor than another. The impact of isolation, either inherent in remoteness or by the decline of early interaction networks (Weisler 1996), was doubtless influential in the prehistoric abandonment of most of the subtropical islands (Norfolk, Kermadecs, Pitcairn, Henderson), but Rapa, and especially Easter Island, were also isolated. Survival on those probably depended on the greater resource availability of a much longer coastline (Easter) or a large harbour (Rapa), coupled with the development of agricultural systems absent or little in evidence elsewhere in the subtropical islands.

Even so, it can be hypothesised that levels of competition for resources had reached quite extreme levels by late prehistory. On Rapa, there may have been 10 competing polities, each the proud lords of, on average, fewer than $4 \mathrm{~km}^{2}$ of land, nearly all of it steep and largely 
barren. Perhaps only such a level of competition can have made the labour and inconvenience of building and living in the skyline forts seem at all worthwhile.

\section{Further research}

We are well aware of the preliminary nature of our investigations on Rapa and the probability that our results and conclusions will need significant modification in future research. The need for more research is urgent. Increasing development of roads, housing and other facilities has already exposed numerous sites around Ha'urei Harbour; sand deposits needed for concrete are scarce and the largest of them underlies the oldest site on Rapa, at Tangarutu, which is now about $85 \%$ destroyed by sand mining; major works, including the development of an airfield, are envisaged. In addition, grazing cattle and, especially, a large population of feral goats have created massive hillslope erosion in many bays. Even without these mechanisms of accelerating site damage, the forts are decaying rapidly. The substrates are mostly saprolitic clays and weathered basalts, which erode quickly in the absence of forest cover and soon bring down masonry and other structures. There is, we suggest, a need for prompt and serious attention to the archaeology of Rapa well beyond that which our resources could meet.

Among those aspects of Rapan archaeology which demand attention are these:

1. Establishing the sequence of cultural landscape development in much more detail. We used AMS ${ }^{14} \mathrm{C}$ dating as a survey technique (Chapter 11 ) to establish the broad pattern of landscape use, but that is a relatively crude, if initially useful, approach, which, ideally, would be superseded by high-density dating to determine temporal relationships between site clusters, types, localities (such as the individual valley systems), and individual sites and stratigraphy. Some of this research needs to be directed at the major colonisation sites, especially Tangarutu.

2. One particular set of archaeological features, critical to understanding the development of Rapan prehistory, and which has yet to be investigated systematically, consists of the pondfields (Chapter 13) and associated structures. The history of these offers a means of testing conjecture about the trajectory and chronology of population growth and the development of pressure on resources that underlies an economic proposition for the rise of warfare and fortifications.

3. Another set of features, mostly located on low ground behind the coast, or on low hills and ridges, and consisting mainly of terraces, but also ovens, hearths, burial areas defined by stone kerbing, and the ethnographically recorded remains of rudimentary marae, may refer to what is currently a poorly resolved middle phase in Rapan prehistory. We, and others before us, have barely touched on these features.

4. Much more excavation is needed, preferably in large open areas, of the surviving pare. Too little is known of how habitation on these sites was organised, whether there were houses of different sizes and locations, to what extent different economic and technological functions were carried out at them, how long settlement lasted at different sites, whether agricultural storage was indeed a major purpose, and whether conjecture about sociopolitical relationships between major and minor pare can be sustained. 


\section{Note}

1. There are very small lagoons on Norfolk Island.

\section{References}

Anderson, A.J. 1981. The archaeology of Raoul Island and its place in the settlement history of Polynesia. Archaeology and Physical Anthropology in Oceania 15:131-141.

Anderson, A.J. 1996. Origins of Procellariidae Hunting in the Southwest Pacific. International Journal of Osteoarchaeology 6:1-8.

Anderson, A.J. 2001. No meat on that beautiful shore: the prehistoric abandonment of subtropical Polynesian islands. In: Anderson, A.J. and Leach, B.F. (eds), Zooarchaeology of Oceanic Coasts and Islands: Papers from the 8th International Congress of the International Council of Archaeozoology, 23-29 August 1998, Victoria B.C., Canada. Special Issue of the International Journal of Osteoarchaeology 11:14-23.

Anderson, A.J. 2002. Faunal collapse, landscape change and settlement history in Remote Oceania. World Archaeology 33:375-390.

Anderson, A.J. and White, J.P. (eds), 2001. The Prehistoric Archaeology of Norfolk Island, Southwest Pacific. Records of the Australian Museum, Supplement 27, Sydney.

Buck, Sir P.H. 1954. Vikings of the Sunrise. Whitcombe and Tombs, Christchurch.

Heyerdahl, T. and Ferdon, E.W. (eds), 1965. Reports of the Norwegian Archaeological Expedition to Easter Island and the East Pacific, Volume 2 Miscellaneous Papers. Monographs of the School of American Research and the Kon-Tiki Museum, 24 Pt. 2, Esselte AB, Stockholm.

Lamb, W.K. (ed), 1984. George Vancouver, A Voyage of Discovery to the North Pacific Ocean and Round the World 1791-1795, Volume I. The Hakluyt Society, London.

Mieth, A. and Bork, H-R. 2004. Easter Island - Rapa Nui: scientific pathways to secrets of the past. Man and Environment 1. Christian-Albrechts-Universität zu Kiel, Kiel.

Walczak, J. 2003. Presentation des données actuelles sur la préhistoire de Rapa Iti (archiple des Australes-Polynésie Française). In: Orliac, C. (ed), Archéologie en Océanie Insulaire: Peuplement, sociétés et paysages, pp. 28-45. Editions Artcom, Paris.

Weisler, M.I. 1996. Taking the mystery out of the Polynesian 'mystery' islands: a case study from Mangareva and the Pitcairn group. In: Davidson, J., Irwin, G., Leach, F., Pawley, A. and Brown, D. (eds), Oceanic Culture History: essays in honour of Roger Green. New Zealand Journal of Archaeology, Special Publication, pp. 615-629. Dunedin.

Wilmshurst, J., Hunt, T., Lipo, C. and Anderson, A. 2011. High-precision radiocarbon dating shows recent and rapid initial human colonization of East Polynesia. Proceedings of the National Academy of Sciences 105:7676-7680. 